\title{
Enhancing aid effectiveness: The Case for stronger local government involvement in development
}

\section{Commonwealth Journal of Local Governance \\ Issue 6: July 2010 \\ http:/lepress.lib.uts.edu.au/ojs/index.php/cjlg}

\section{Federation of Canadian Municipalities}

In 2008-2009, the Federation of Canadian Municipalities and the Capacity and Institution Building Working Group (CIB) of United Cities and Local Governments (UCLG) led the development of a UCLG Position Paper on Aid Effectiveness and Local Government. ${ }^{1}$ The position paper was adopted unanimously by UCLG World Council members at their annual meeting in Guanghzou, China in November 2009. It seeks to give voice to the local government perspective in the continuing deliberations on aid effectiveness. The paper also provides specific policy recommendations for the international donor community, national governments and local governments themselves geared towards better incorporating local governments into the design and delivery of development programs and processes.

\section{The issue: Local governments are agents of development}

As politically legitimate and accountable community leaders, local governments play a valuable convening role that brings together development stakeholders (civil society, community groups, policy-makers) to help shape and implement development policies and programs. ${ }^{2}$ Given their responsibility to ensure equitable delivery of essential services, including in many cases social services around health, welfare, and housing, combined with their ability to replicate successes for community-wide benefit, local

\footnotetext{
${ }^{1}$ Local government refers to a governing institution which has authority over a sub-national territorially defined area; in federal systems, a sub-state territorially defined area. These include towns, cities, counties, districts and regions governed in most cases by locally elected officials. Local governments' jurisdictional and administrative authority varies depending on the degree of decentralization and the national governance structure in a given country.
} 
governments occupy an important niche and must be recognized as valued partners by the development community. ${ }^{3}$

Furthermore, local governments, through decentralized cooperation, ${ }^{4}$ are playing an important role in the delivery of aid through peer-to-peer cooperation. Local governments and their associations mobilize community assets and significant resources that complement the financial contributions from donors. The delivery of these resources through programs and projects that are co-managed by 'southern' and 'northern' partners promote mutual accountability and enhance local capacity to plan, manage, implement and report on results.

Awareness about the role of local governments in development cooperation is gradually increasing. The Accra Agenda for Action (AAA), which was the result of the mid-term 3rd High Level Forum on Aid Effectiveness in Accra, Ghana (2-4 September 2008), includes specific timelines and recognizes the importance of democracy, improvement of governance, social progress and environmental challenges as prime engines of development. The role of local governments has explicitly been recognized in the development of national development policies. The AAA also recognizes the need to support capacity building initiatives of local authorities and emphasizes the importance of local resources in the provision of technical cooperation.

\section{Why invest in local governments?}

Approximately half the world's population currently lives in urban areas and it is estimated that this will grow to as much as $60 \%$ by 2015 . Virtually all of this growth will occur in the developing world, resulting in severe social and economic inequities and escalating rates of poverty. This extraordinary rate of urban growth is transpiring alongside widespread rural exodus, placing an enormous burden upon both rural and urban local governments, as they struggle to put in place responses to deal with the effects of these unprecedented demographic shifts. In this context, local and regional authorities will become both key development actors and the target of development cooperation. In addition, fast growing urbanization is giving rise to a major and pressing

\footnotetext{
${ }^{3}$ UN Millennium Development Goal 8 calls for a global partnership that brings together the private sector, non-governmental organizations, civil society and foundations to help leverage resources for the implementation of pro-poor urban and rural development strategies. Local governments should play a central role as partners in development.

${ }^{4}$ Decentralized cooperation is used here to describe the publicly and privately funded aid provided by and through local authorities, local government associations, networks and other local actors.
} 
need for future infrastructure projects that are expected to cost some USD 200 billion per year over the next 25 years. However, these infrastructure needs are currently being unmet. Failure to invest in infrastructure has already impacted severely upon the daily lives of millions of citizens in developing countries. The achievement of the main international development commitments such as the Millennium Development Goals ${ }^{5}$ and the global fight against climate change and its impacts will be won or lost in the urban areas of the planet, and particularly in the slums where one out of five persons will live by 2020 .

\section{Policy recommendations}

Donors, multilateral and bilateral financial institutions, central governments and international organizations are called on to:

1. Formally recognize local governments as development actors in future development compacts and promote their participation in a systematic way in all stages of the development process.

2. Support the recognition of local governments and their associations (LGAs) as legitimate development partners in the 2008 Accra Agenda for Action, and welcome the recognition of the World Organization of United Cities and Local Governments to become members of the OECD/DAC Working Party on Aid Effectiveness and the Advisory Board of the UN Development Cooperation Forum. This recognition should be expanded to all national and donor led consultations.

3. Attach a fundamental importance to decentralization as an important building block for good governance and effective development assistance at the local level.

4. Given its relevance as an indicator of a country's development performance, governance ${ }^{6}$ should be a cross-cutting theme for central governments and donors in the same manner as gender equality, human rights and environmental sustainability so that it receives greater consideration during policy and program development.

5. Adopt a more integrated approach to strengthening local governance that combines working locally, nationally, regionally and globally. This approach will facilitate the scaling-up of successful practices and enable local community leaders to engage in

\footnotetext{
5 The Millennium Development Goals (MDGs) adopted by the United Nations in 2000 are eight time-bound targets to end extreme poverty by 2015.

6 Governance refers to the process or approach for managing political, economic and administrative authority. The system of governance will determine how governments are selected or changed and the process through which citizens and groups define their interests and interact with institutions of authority, as well as with each other. Good governance accomplishes this in a manner that is essentially free of abuse and corruption and with due regard for the rule of law.
} 
dialogue at the national level to positively influence public policies that will lead to transformative change and sustainable development at the local level.

6. Put in place formal consultation mechanisms to strengthen coordination between local and national governments and donors, particularly with respect to policy formulation, planning, implementation, monitoring and evaluation of national development strategies.

7. Offer a balance of aid delivery mechanisms (e.g. projects, program based approaches, budget support and technical assistance) to support governance and decentralization that will ensure that local authorities have the mechanisms to respond with sufficient flexibility in different contexts. Aid channeled through budgetary support and sector-wide approaches (SWAps) must be designed in a manner that recognizes and reinforces the legitimate role of local authorities as credible public institutions and agents of development.

8. In the context of decentralized cooperation, put in place mechanisms that allow local governments and/or local government associations to directly manage international cooperation programs that focus on: strengthening the capacity of the local government sector; promoting democracy at the local level, and; supporting decentralization. $^{7}$

9. Strengthen the capacity and strategic partnering role of local governments to engage in multi-stakeholder dialogue on national development strategies and in policy discussions with the OECD Working Party on Aid Effectiveness and the United Nations Development Cooperation Forum.

10. Strengthen the resources accessible to local authorities. It is proposed that $20 \%$ of international aid (currently provided in the form of budgetary support and sector wide approaches) be earmarked to support decentralization processes and the capacity building of local government. ${ }^{8}$

11. Improve the transparency of aid management, such that resource flows to various sectors, including local government, can be monitored.

Local governments and local government associations are called on to:

\footnotetext{
7 Consultation with local government can help ensure closer alignment of central government and donors' plans and programs with community needs, particularly where local governments are involved in participatory municipal planning and budgetary processes.

${ }^{8}$ UCLG proposes that at least 20\% of public development aid (about USD 20 billion) be allocated directly to local governments or through decentralized cooperation. UCLG Policy Paper on Local Finances, UCLG (2008:13)
} 
12. Engage in a dialogue with donors and central governments to ensure that the needs and concerns of local governments are clearly understood and supported by relevant policies and programs.

13. Ensure that the voices of the full diversity of the community are heard by promoting participatory processes further applying this principle to decentralized co-operation which should be based on strong demand from the beneficiary.

14. Ensure that decentralized cooperation approaches, such as municipal international cooperation (MIC) and association capacity building (ACB), are well coordinated and developed within the framework of southern-driven agendas that take into account the local cultural context, country processes and governance reform programs, concretized in country strategies for municipal sector development.

15. Strengthen the voice of national and regional associations, as well as the World Organization of United Cities and Local Governments, to advocate local governments' interests internationally.

16. Develop a community of practice that will facilitate the sharing of knowledge, tools and lessons learned in the areas of MIC and ACB, which builds on the experience of the existing Committees and Working Groups of UCLG, particularly the CIB (Capacity and Institution Building Working Group).

17. Promote long-term partnerships between local governments and partner countries, international organizations, bilateral and multilateral donors, in addition to other key stakeholders such as parliamentarians and civil society.

\section{Future Work}

UCLG's continued work in this area, through its Capacity and Institution Building Working Group, will:

- assist local governments and local government associations in taking forward the approved position;

- maintain its dialogue with multilateral institutions in preparation for the 4th High Level Forum on Aid Effectiveness in Seoul, Korea in 2011; and

- continue to provide a platform for strengthening program coordination and aid effectiveness among local governments and local government associations active in decentralized cooperation. 
For a more detailed overview of how the local government sector contributes to each of the Paris Declaration principles, see the support paper that accompanies the UCLG Position Paper on Aid Effectiveness and Local Government. The paper also includes several case studies that demonstrate how local governments are contributing to the effective delivery of aid. ${ }^{9}$

This Commentary first appeared in March 2010 as an FCM Issue Briefing paper on that organization's website: $<$ http://www.cities-

localgovernments.org/upload/doc publications/9243688416_(EN)_uclgpositionpaperen.pdf> (696KB)

9 Available online on the UCLG website: www.cities-localgovernments.org 